International Journal of Business and Management 2 (5): 16-20, 2018

e-ISSN: 2590-3721

(C) RMP Publications, 2018

DOI: $10.26666 /$ rmp.ijbm.2018.5.3

\title{
Practices of Managing Tax Records Keeping among the Academic Staff
}

\author{
Elyn Mohd Ridzwan ${ }^{1}$ Hasnida Ibrahim ${ }^{2}$ \\ Jabatan Perdagangan, Politeknik METrO Johor Bahru, \\ Taman Putera 81100, Johor Bahru, Johor, Malaysia
}

\begin{abstract}
This study was carried out in order to investigate the level of awareness among the civil servants (academic staff) on the practice of tax records keeping management for IRB's audit and tax investigation purposes. A total of 200 respondents from 10 educational institutions have been involved in this study. The implemented research design was based on quantitative survey that use questionnaire as research instrument. The data were analyzed using SPSS (Statistical Package for The Social Science) software version 2.0 in order to determine the mean score. The result obtained from this study shows that the public awareness among the academicians on record management is still low.
\end{abstract}

Keywords: Tax records management, tax evasion, academic staff, Inland Revenue Board (IRB)

\section{INTRODUCTION}

Taxation is a growing field of knowledge and is influenced by the economic development of a country. Taxation is also one of the important instruments that serves as a major contributor to the national income. The rationale for this tax implementation is to enable a government to finance the expenditure and development of the country and at the same time to balance the income gap between the high income earners and low income earners [1]. Although knowing that taxation is something that benefits all, there are certain parties who attempt to avoid or escape the tax payments hence triggering a tax non-compliance situation [2].

The implementation of a fair, efficient and effective tax system is very important to the tax administrator so that its functions can be recognized and respected by the people and this can also contribute to the progress of the country. Therefore, IRBM (Inland Revenue Board of Malaysia) is constantly working to improve its provided service in order to facilitate the taxpayers during performing their taxation responsibilities. According to Hijattulah [3], in the Malaysia's taxation system, the tax compliance touches on a few aspects including; storage of records, understanding related to allowable expenses and taxable income, filling or filing the tax forms and paying taxes. When the selfassessment system is fully implemented starting in 2004, the taxpayers are required to manage their own taxes, keeping records in order and filling the real income statements correctly and transparently. This self-assessment system requires high commitment from each individual as they need to understand the tax laws in order to enable them to fill and calculate their own tax liability. Also, this system demands voluntary tax compliance too. However, without the understanding and positive attitude regarding the tax system, the taxcompliance situation will be hard to achieve. Every year, each taxpayers is responsible to report their income and accurately calculate their tax liability throughout the year of assessment in order to be given to the relevant authorities. Each receipt and supporting documents need to be kept in order to serve as the supporting documents for every rejection made. The Inland Revenue Board (IRB) relies on the honest income report by each taxpayer. However, appropriate checking was also conducted by IRB in order to verify the earnings information provided by the taxpayers. If the taxpayers fail to properly report their income information, actions and penalties will be imposed. The inspection on tax report or tax audit is carried out for every 5 to 7 years or possibly more often depending on the IRB. The tax audit can be defined as an investigation of the individual documents or business accounts including the taxpayers' finances, in order to check whether taxes have been reported and paid in sufficient amount and the tax laws are fully complied with Mohd Rizal [4]. There are two types of audits which are usually carried out including desk audit and external audit. The desk audit can be conducted even

Corresponding Author: Hasnida Ibrahim, Politeknik METrO Johor Bahru, No.64 Taman Suria 81100 Johor Bahru, 0194604277 
without the presence of a tax auditor at the taxpayer's premises. This tax adjustment process is simple; the taxpayer will receive a letter from the IRBM or the taxpayer may be called to the IRBM office for an interview if any additional information is needed. Whereas for external audit, the tax audit will be conducted at the taxpayer's premises. This process involves reviewing the business records as well as the non-business records of the taxpayers. The taxpayer will be informed prior to the external audit visit. According to the Income Tax Act 1967, the annually conducted tax transactions requires taxpayers to keep their tax records for seven years from the end of the assessment year, in order to determine the validity of their accounts and allow comparison if necessary. During the auditing process, these records and documents are required to support the expenses claim made in the submitted Income Tax Return Form (ITRF). In the case of an individual income tax assessment, the taxpayer may be fined and imprisoned if all purchase receipts including for books, sports equipment and computers are fail to be proven. The tax exemption claimed by individuals in the selfassessment system requires them to efficiently manage the receipts and invoices so that IRB's audit and tax investigation process can run smoothly and the individuals must also be able to present the evidence at the required time when the IRB wants to revise the originality of the taxpayer's claim. It is even stated in Section 119A of the Income Tax Act 1967 that an individual can be fined as much as RM300 to RM10,000 or jail or both for the offense of not keeping the records. Based on IRB's Public Ruling (PR), taxpayers do not have to send the original documents/receipts along with the ITRF, but these documents should be kept for 7 years. These documents are represented by income and expense statements, as well as any invoices, vouchers, receipts, and any other documents that may verify the details of tax returns. According to Section 82A (4), the individuals need to keep any electronic records in an easily accessible format. The individuals should also make copies of the receipts in order to avoid the ink fading problem on the receipts. Hence, exclusive and inclusive attention and awareness should be given out in managing the tax records in order to reduce the risk of penalties imposed on taxpayers for failing to provide sufficient evidence during the audit investigation.

\section{OBJECTIVE OF STUDY}

Among the main objectives of this study are:

i. To identify the knowledge of the academic staff on the practice of managing the tax records keeping

ii. To identify the attitudes of academic staff towards the practice of managing the tax records keeping iii. To identify the level of awareness among the academic staff on the importance of practicing the tax records keeping management.

\section{SIGNIFICANCE OF STUDY}

This study focuses on the practices of managing tax records keeping among the academic staff at several educational institutions throughout Malaysia. The outcome of this study is expected to provide an important information in order to discover and evaluate the effectiveness of the tax compliance enforcement policies among Malaysians hence providing the best mechanisms towards zero failure case in tax records keeping. This study is also useful for enforcement policy implications in the context of groups that require guidance about the tax education program, in which this program will emphasize more on developing positive attitudes towards record management by using different strategies.

\section{LITERITURE REVIEW}

Management of records and documents is an activity providing efficient and systematic control over the creation, use, maintenance and disposal of records. This control includes evidence capturing and information on an organization's activities and transactions [5].

The importance of document record management is not neglected by educational institutions. Document records are important as references and evidence which need to be extracted and required by an organization in the future and must be properly maintained as contained in the National Archives Act 2003 and General Circular Letter. No. 1/1997 namely the Preservation of Government Records and Service Directive Chapter 5.

Even the characteristics of a good filing system are systematic, easy to refer, easy to obtain and safe. Managing a well-organized tax records will simplify the audit and investigation process from the authorities. Without the effective management of the system, it is not possible to risk human negligence such as the mismanagement of documents and the loss of documents [6].

The ability of an institution to deliver services, make decisions and execute quality transactions is dependent on the extent to which information is required to be created, stored, achieved and used [7]. The importance of the documents provided when needed is undeniable and it is also a symbol of the competence of an individual. In fact, the government through some instrumental instruments also emphasizes the accountability and transparency of public services that 
can only be disclosed through a complete, authentic, accessible and usable record.

\section{PROBLEM STATEMENTS}

As the agency which manages the country's direct taxes, LHDNM is responsible for ensuring the tax compliance activities is implemented among Malaysians. IRBM has continuously organized the tax awareness activities such as briefing sessions to employers at government and private agencies, strategic cooperation with professional bodies and Higher Education Institutions, off-site counter services at selected locations, distribution of the tax-related brochures to the public, publicity, interviews and tax issuance. However, the tax non-compliance activities still occur among Malaysians.

Tax non-compliance is a continuous issue faced by most tax administration bodies including the Inland Revenue Board of Malaysia (IRBM). The IRBM defines the tax non-compliance as the failure of an individual or entity to register, submit tax forms within a prescribed time, report the correct amount of income and failure to keep sufficient records. In accordance of Section 82 of the Income Tax Act (ITA), the taxpayers are required to keep adequate and complete records so that the income or income loss can be determined. As already stated in Public Ruling No. 4/2000, No. 5/2000 and No. 6/2000, the "record" interpretation includes invoices, vouchers, receipts and any other documents necessary to verify any matter recorded in the account book. Failure to keep sufficient and complete records is an offense under Section 119A of the ITA. (Audit Financial Assessment Framework_1).

Those who are engaged in tax non-compliance activities are not only represented by certain groups but they also come from various parties including government employees [8], academic staff [9] as well as small and medium-sized businesses - PKS [10]. The result of audit operation found that there was an increase in the number of taxpayers who failed to keep sufficient records between 2014 and 2016 which in total consist of 8,735 cases, [11]. It still shows a large number of cases reflecting the attitude among taxpayers who do not manage their files preferably.

\section{RESULT AND DISCUSSIONS}

A total of 200 respondents have responded to the questionnaires that have been distributed. Table 4.1 describes the number of respondents according to the research institution.

\begin{tabular}{|c|c|c|}
\hline Institution & $\begin{array}{c}\text { Number of } \\
\text { Respondents }\end{array}$ & $\begin{array}{c}\text { Percentage } \\
(\%)\end{array}$ \\
\hline Public university & 20 & 10 \\
\hline Polytechnic & 90 & 45 \\
\hline Community college & 50 & 25 \\
\hline Secondary school & 40 & 20 \\
\hline Total & $\mathbf{N = 2 0 0}$ & $\mathbf{1 0 0}$ \\
\hline
\end{tabular}

Table 4.1 The total number of respondents according to the institution. $(n=200)$

Table 4.2 shows that 65 percent or represented by 130 respondents consist of women while 35 percent or represented by 70 respondents consist of men. While Table 4.3 shows that the majority of respondents in this study that aged between 36 and 45 years old are represented by $39 \%$ of the respondents, $35 \%$ of the respondents aged from 28 to 35 years old, and $27 \%$ of the respondents are over 46 years old.

\begin{tabular}{|c|c|c|}
\hline Gender & Frequency & $\begin{array}{c}\text { Percentage } \\
(\%)\end{array}$ \\
\hline Male & 70 & 35 \\
\hline Female & 130 & 65 \\
\hline Total & $\mathbf{N = 2 0 0}$ & $\mathbf{1 0 0}$ \\
\hline
\end{tabular}

Table 4.2 The distribution of respondents according to gender

\begin{tabular}{|c|c|c|}
\hline Age & Frequency & $\begin{array}{c}\text { Percentage } \\
(\%)\end{array}$ \\
\hline $26-35$ & 69 & 34.5 \\
\hline $36-45$ & 77 & 38.5 \\
\hline $46-55$ & 54 & 27 \\
\hline Total & $\mathbf{N}=\mathbf{2 0 0}$ & $\mathbf{1 0 0}$ \\
\hline
\end{tabular}

Table 4.3 The distribution of respondents according to Age

The respondents' income level is shown in Table 4.4 where the highest percentage of $44.5 \%$ represents those with income between RM4000 to RM5000. This is followed by $35 \%$ of the respondents with income of RM5000 and above, then $20.5 \%$ of the respondents earn between RM3000 and RM4000. The majority of the respondents have been involved with the Scheduled Tax Deduction (STD) process which includes in 89.5 percent of the total sample. 


\begin{tabular}{|c|c|c|}
\hline $\begin{array}{c}\text { Income level } \\
(\mathrm{RM})\end{array}$ & Frequency & $\begin{array}{c}\text { Percentage } \\
(\%)\end{array}$ \\
\hline 3000 to 4000 & 41 & 20.5 \\
\hline 4000 to 5000 & 89 & 44.5 \\
\hline 5000 and above & 70 & 35 \\
\hline Total & $\mathbf{N}=\mathbf{2 0 0}$ & $\mathbf{1 0 0}$ \\
\hline
\end{tabular}

Table 4.4 The distribution of respondents' income

\begin{tabular}{|c|c|c|}
\hline $\begin{array}{c}\text { Involvement } \\
\text { with STD }\end{array}$ & Frequency & $\begin{array}{c}\text { Percentage } \\
(\%)\end{array}$ \\
\hline Involved & 179 & 89.5 \\
\hline Do not involved & 21 & 10.5 \\
\hline Total & $\mathbf{N}=\mathbf{2 0 0}$ & $\mathbf{1 0 0}$ \\
\hline
\end{tabular}

Table 4.5 The distribution of respondents' involvement with STD

The findings from the questionnaires were analyzed to determine the percentage and the mean score values. In order to analyze the meaning of mean score values based on the four-point Likert scale, the interpretation for this study is made according to the two point justification including low and high level. The tendency of the respondents to response as strongly agree, agree, disagree and strongly disagree is based on the table below:

\begin{tabular}{|c|c|}
\hline Mean score & Interpretation \\
\hline Mean $=1.00-2.50$ & Low \\
\hline Mean $=2.51-4.00$ & High \\
\hline
\end{tabular}

Therefore, the mean score values obtained from the analysis of this study is based on this table. The findings of this study will be based on these 3 research questions including:

i. How far is the knowledge of academic staff towards the practice of managing the tax records keeping?

ii. What are the attitudes of academic staff towards the the practice of managing the tax records keeping?

iii. What is the level of awareness among the academic staff towards the importance of practicing the tax records keeping management?

The analysis found that $94.6 \%$ of the staff had knowledge about auditing and tax investigation as well as the responsibility to proficiently manage the tax records. The management of the records and documents contribute to the improvement of the organizational performance apart from being the evidence for the record management implementation practices as reported by Archives New Zealand [12].
The policy which follows the best performing code is of help for the organizations in order to avoid the legal issues and misappropriation of record access. All organizations need to store and maintain the related business records in order to meet the operational requirements [13]. A total of 10 questions related to basic knowledge of audit, tax investigation and management of tax records have been tested. As overall, all these 10 items show high values of mean score which range between 3.11 and 3.89. This high level of agreement illustrates their good understanding and knowledge regarding this issue which then answers the first research question.

Since almost $74 \%$ of the respondents never undergone an audit process from IRB, thus they are not concerned with the issues raised in the second research question. The respondents even assume that the failure in presenting the transaction receipt during claiming the tax relief is not a serious offense. Thus, they often encounter problems in finding receipts or past documents when they are needed. This can be further proven by low mean score of 2.31 . However, there are a few respondents who take a safe step by storing transaction receipts neatly and having a special place for them for more systematic and accessible tax purposes. In conclusion, this study found that the respondents' overall attitudes towards the practice of tax records storage management are less favorable in which the analysis for the level of agreement for each item (B11 to B16) shows low mean score between 2.15 and 2.49 representing low support level. While $5 \%$ of the respondents who have undergone the audit and tax investigation show positive attitudes towards the management of tax records storage.

Each items in section $\mathrm{C}$ (C17 up to item $\mathrm{C} 22)$ requires the respondents to provide information on their awareness of the importance of managing the tax records. Once the items are analyzed in detail based on the mean score values obtained for each part, this generates different mean positions. The analysis shows that the level of awareness for the majority of the respondents is at low level where each item receives a mean score between 2.00 and 2.49. This low level of agreement reflects that they feel no urgent need for the practice of managing the tax records storage. Furthermore, this practice gives no added value in the smoothness of their work performance. However, some of them are aware of the need to create a consistent tax records storage mechanism.

\section{CONCLUSIONS AND RECOMMENDATIONS}

From the observation, it can be concluded that the academic staff at educational institutions have sufficient knowledge about tax audits as well as 
document recording processes for tax investigation purposes. However, the knowledge itself is insufficient for the success of a process if the implementation of the practices is not done simultaneously. The common attitudes and perceptions that record management is not something to be given priority should be eliminated from all civil servants' mentality. The existing level of awareness needs to be enhanced in order to produce the academic staff who have excellent professionalism towards the implementation of processes and procedures set by the government. The finding of this study is also able to provide relevant inputs to IRBM in assisting them in developing a more structured and specific enforcement strategy. Proactive steps need to be taken in order to provide knowledge and understanding of proper and orderly record keeping practices and at the same time help the taxpayers in reducing the unexpected risks during audits. And of course the desire to see Malaysia as a developed country could not be achieved if the tax auditing activity is not systematically implemented. After analyzing and interpreting all the data, there are several suggestions that can be considered to improve the factors that contribute to the public's awareness on the importance of tax records storage management. Among the significant suggestions is to create a consistent and compact tax records storage medium for the purpose of an audit investigation, which can be applied by all the taxpayers. However, further investigation needs to be done in order to examine the limiting factors to the proper tax records storage management besides studying what steps should be taken in order to develop a positive attitude towards the practice of keeping the tax records. The initial approaches that need to be taken are to increase the exposure and understanding of fiscal policy and to fix the negative perceptions regarding audit investigation activities so that the taxpayers can develop more exclusive thinking and take into consideration on the importance of practicing the tax records keeping management.

\section{REFERENCES}

[1]Lymer, A., and Oats, L. (2009). Taxation: Policy and Practice. $16^{\text {th }}$ ed. Birmingham: Fiscal Publications.

[2]Natrah Saad, (2012). Tax Non-Compliance Behavior: Taxpayers' View. Prodecia- Social and Behavioral Sciences 65 (2012) 344-351.

[3]Hijattulah Abdul Jabbar. (2009). Income Tax Noncompliance of Small and Medium Enterprise in Malaysia: Determinants and Tax Compliance Costs. Curtin University of Technology.

[4]Mohd Rizal Palil. (2010). Tax Knowledge and Tax Compliance Determinants in Self Assessment System in Malaysia. University of Birmingham. Retrieved from http://etheses.bham.ac.uk/1040/

[5] Malaysian Standard MS 2223-1: 2009. Retrived fromhttp://jksns.ns.gov.my/images/unit_rekod/02MALAYSIAN-STANDARD-2223-1--2009.pdf

[6]James J. Heckman. (2008). Schools, Skills and Synapses. NBER Working Paper No 14064.

[7] Dasar Pengurusan Rekod Kerajaan ANM.SDSPK.7/2010

[8]Ming Ling Lai, Zalilawati Yaacob, Normah Omar, Norashikin Abdul Aziz, \& Bee Wah Yap. (2013). Examining Corporate Tax Evaders: Evidence from the Finalized Audit Cases. World Academy of Science, Engineering and Technology, 78(6), 396400.

[9]Syatila Che Saruji, \& Mohd Rizal Palil. (2012). Pengelakan Cukai : Kajian Kes Di Kolej Poly-Tech MARA , Kuala Lumpur ( KPTMKL ). In Prosiding PERKEM VII (Vol. 2, pp. 1067-1081).

[10]Ming Ling Lai, Zalilawati Yaacob, Normah Omar, Norashikin Abdul Aziz, \& Bee Wah Yap. (2013). Examining Corporate Tax Evaders: Evidence from the Finalized Audit Cases. World Academy of Science, Engineering and Technology, 78(6), 396400.

[11]Lembaga Hasil Dalam Negeri Malaysia. (2014). Laporan Tahunan LHDNM 2013-2016.

[12]Archives New Zealand. (2002). Electronic records: A vision and policy for the New Zealand government sector

[13]Hatfield, J. (2002). How much will your email cost? E.Doc 16(3): 17 